\title{
TURISMO, ESPAÇO E PAISAGEM - LEITURAS DO AMBIENTE URBANO
}

\author{
TOURISM, SPACE AND LANDSCAPE - URBAN ENVIRONMENTAL ANALYSIS
}

\section{GONDO, Silvia N.}

Bolsista PIBIC CNPq/UFSC, Grupo de Pesquisa de Informática na Arquitetura (INFOARQ) - Departamento de Arquitetura/UFSC.

E-mail: silviananami@yahoo.com.br

\section{REBOLLO SQUERA, Jorge H.}

Arquiteto e mestrando do Programa de Pós-Graduação em Arquitetura e Urbanismo/UFSC.

E-mail: rsqiorge@terra.com.br

\section{SANTIAGO, Alina G.}

Arquiteta, doutora da Université de Paris I - França, e professora do Programa de Pós-Graduação em Arquitetura e Urbanismo - Grupo de Pesquisa de Informática na Arquitetura (INFOARQ) - Departamento de Arquitetura/UFSC.

E-mail: alina@arq.ufsc.br

\section{RESUMO}

A atividade turística, consolidada na região na década de 1980, é responsável por grande parcela do movimento econômico de Florianópolis. Essa atividade acarreta várias mudanças na paisagem em que é realizada, sejam elas boas, como a tecnologia e o desenvolvimento levado à região, ou ruins. As conseqüências negativas são ainda agravadas quando o turismo acontece sem um planejamento coerente. A ocupação desordenada da ilha, seja por moradores locais ou equipamentos turísticos, implicam na saturação da malha viária, destruição das áreas de preservação, polvição das águas. Conseqüências estas que ocorreriam em qualquer ecossistema, mas torna-se pior pela frágil condição de llha e difícil recuperação das características originais. Para se evitar ou suavizar esses efeitos negativos será feito um estudo da ocupação dos equipamentos turísticos na llha, analisando as áreas de maior concentração e prejuízos decorrentes desta ocupação.

Palavras-chave: Turismo, paisagem, transformação da paisagem.

\begin{abstract}
The tourist activity, consolidated in the region at the 80 's, is responsible for a big amount of the economic movement in Florianópolis. This activity causes many changes at the landscape where it is done, either good, like the technology and development lead to the region, or bad. The bad consequences get still worse when the tourism happens without a great planning. The disordered occupation of the Island, either by the local inhabitant or by tourist equipment, gets to a saturation of the streets, destroying the preserved areas, polluting the water. These results would occur in any ecosystem, but gets worse by the fragile condition of an Island and hard recovery of the original individuality. To avoid or alleviate those bad results will be studied the tourist equipment occupation in the Island, analyzing the areas with the biggest concentration and harms caused by that.
\end{abstract}

\section{Key words: Tourism, landscape, urban changes.}

\section{Introdução}

A llha de Santa Catarina é muito conhecida por suas belas praias e atrativos naturais, por isso, tem o turismo como grande impulsionador de sua economia. Porém, o crescente número de turistas e moradores na llha começa a causar conflitos. A vulnerabilidade do local fica visível quando se observam a proliferação de equipamentos turísticos em áreas impróprias, a carência de infra-estrutura, a deterioração da paisagem natural e a falta de um planejamento turístico. 
Tendo como objetivo incentivar o turismo e ao mesmo tempo propiciar qualidade de vida para os moradores locais, surge a necessidade de estabelecer políticas públicas de turismo.

A Organização Mundial do Turismo - OMT assinala a "capacidade de carga" como conceito fundamental para o turismo sustentável, sendo essa capacidade definida como o número de turistas que um espaço pode receber sem prejuízos físicos em seus ecossistemas ou em seu meio ambiente artificial, sem incomodar a comunidade e as culturas locais e a qualidade de experiência turística (KNAFOU, 1996). E é com o intuito de verificar a "capacidade de carga" da ilha de Santa Catarina que se desenvolve essa pesquisa, assim como examinar as conseqüências causadas nos locais em que essa capacidade já foi ultrapassada.

\section{Ilha de Santa Catarina}

Florianópolis, capital do estado de Santa Catarina, recebeu esse nome em homenagem ao Marechal Floriano Peixoto após a vitória dos republicanos na "Revolução Federalista". Como esse nome carrega toda uma história trágica, Desterro, seu antigo nome, é chamada por seus moradores de llha de Santa Catarina ou, simplesmente, Ilha. Com uma área de aproximadamente $423 \mathrm{~km}^{2}$ e situada entre as latitudes $27^{\circ} 22^{\prime}$ e $27^{\circ} 50^{\prime}$ é ligada ao continente através de três pontes: a ponte Hercílio Luz, inaugurada em 1926 e fechada em 1982 por medida de segurança, atualmente tombada como patrimônio histórico e artístico; ponte Colombo Salles e ponte Pedro Ivo Campos. "Seu relevo é caracterizado pela associação de duas unidades geológicas maiores: as elevações dos maciços rochosos, que compõem o embasamento cristalino, e as áreas planas de sedimentação, delineando, respectivamente, as denominadas serras litorâneas e planícies costeiras, unidades geomorfológicas que caracterizam a paisagem ilhoa" (CECCA, 1997, p. 15). As características climáticas da cidade são próprias do litoral sul brasileiro. As estações do ano são bem diferenciadas, com o verão e inverno bem definidos e o outono e primavera com características semelhantes. Atualmente, o município de Florianópolis está inserido em uma micro-região composta por mais quatro municípios, são eles: Biguaçu, Palhoça, Santo Amaro da Imperatriz e São José. Possui uma grande diversidade de ambientes, tais como praias, dunas, restinga, morros e mangues. Toda essa exuberância de sua paisagem natural não poderia deixar de atrair muitos turistas para a ilha, principalmente no período do verão.

\section{Turismo e espaço}

O turismo é definido pela Organização Mundial de Turismo/Nações Unidas (OMT, 1991) como "as atividades que as pessoas realizam durante suas viagens e permanência em lugares distintos dos que vivem, por um período de tempo inferior a um ano consecutivo, com fins de lazer, negócios e outros". A Embratur tem uma visão mais econômica: "A atividade econômica representada pelo conjunto de transações políticas (compra e venda de bens e serviços)."

No Brasil o turismo já representa 4\% do PIB, o equivalente a 20 milhões de dólares. Mas mesmo assim o país ainda ocupa a 29a posição entre os países que mais atraem turistas. Investidores estrangeiros apontam que isso é, entre outras coisas, devido à sujeira nos espaços públicos, às estradas mal conservadas, à falta de sinalização e ao despreparo das pessoas para lidar com os turistas.

Salientamos os tipos de turismo presentes na Ilha, quanto à motivação: 1) Turismo de lazer: praticado por pessoas que viajam por prazer, sem muitas pretensões. Desejam apenas conhecer novos locais, mudar de ambiente, descansar, rever amigos, visitar parentes, curtir paisagem, sair em férias com a família. É o mais praticado pelos turistas que visitam Florianópolis; 2) Turismo de eventos: praticado por quem deseja participar de acontecimentos promovidos com o objetivo de discutir assuntos de interesses comuns ou para expor ou lançar novos artigos no mercado. 
Esse é um tipo de turismo muito positivo para a llha, pois serve para atrair turistas em todas as épocas do ano, e não apenas na temporada; 3) Turismo desportivo: praticado por pessoas que vão praticar ou assistir a eventos desportivos. Os mais populares na cidade são os aquáticos, especialmente o surfe; 4) Turismo religioso: procurado por pessoas interessadas em visitar locais sagrados, ausente no território da llha, porém presente nas proximidades; 5) Turismo cultural: praticado sobretudo por pesquisadores, técnicos, cientistas, estudantes em busca de novos conhecimentos; 6) Turismo ecológico: praticado por pessoas que apreciam a natureza. Existe um grande potencial para esse tipo de turismo na região devido à beleza do ambiente. Existem muitos outros tipos de turismo, mas esses são os que atraem o maior número de visitantes devido às características locais. Há também outras classificações para o turismo: quanto à idade dos indivíduos (turismo infantil, juvenil, adulto e melhor idade), tipos de transporte (turismo aéreo, rodoviário, ferroviário, fluvial e marítimo), duração (excursão, finais de semana, férias, feriados, eventos específicos, longa e curta duração fora dos demais citados), grupo (individual, familiar, grupal e casais).

O turismo é composto por agentes econômicos que fazem com que ele exista e se sustente. São eles os turistas, as empresas turísticas, o núcleo emissor, o núcleo receptor e o governo. Os turistas evidentemente são os mais importantes pois são eles que compram o produto e fazem movimentar os demais agentes. As empresas turísticas vendem e divulgam os produtos turísticos, são os elos entre o turista e o centro receptor. $\bigcirc$ núcleo emissor é a origem do turista e o núcleo receptor é o lugar visitado. A princípio pode não ser muito visível, mas o governo é um agente econômico do turismo, na medida que é responsável pela construção, melhoramentos e manutenção de estradas, aeroportos, hospitais públicos, segurança pública, saneamento básico.

O início do turismo em Florianópolis se dá por volta de 1970. A partir de então se inicia uma política pública de desenvolvimento turístico, na qual o Estado passa a garantir a implantação da infra-estrutura local necessária para a expansão da atividade. Mas isso não significa que antes não se pensava nessa atividade. Desde a década de 1920 existem projetos não realizados. Entretanto nos anos 80 que ocorre a consolidação do turismo (SANTIAGO, 1995). Sob a pressão dos empresários do setor turístico sobre os recursos públicos, transforma o turismo em "alternativa preferencial de desenvolvimento econômico para o espaço local", provoca certa mistificação, apresentando-o como "atividade redentora" da economia local, como "panacéia" para os nossos males em função dos seus "generosos efeitos redistributivos" sobre o conjunto da população" (CECCA, 1997, p. 214).

O turismo causa diversas alterações no espaço em que é praticado, como a distribuição de renda no local, a aceleração do processo de urbanização e renovação tecnológica, geração de empregos. Entretanto, entre as conseqüências negativas podemos citar a inflação, especulação monetária; destruição dos recursos naturais. Florianópolis convive atualmente com estes conflitos (SANTIAGO, 1995).

\section{Degradação ambiental}

De acordo com a Lei n. 6.938/81 da Política Nacional do Meio Ambiente (Conama, 1981), degradação da qualidade ambiental são as alterações adversas das características do meio ambiente. Essas alterações ocorrem devido a fenômenos geológicos e climáticos e demoram milhões e até centenas de milhões de anos. Mas com o surgimento do homem na Terra o ritmo das mudanças acelera. "Até 1748, data da chegada da primeira leva açoriana, a cobertura vegetal da llha de Santa Catarina não havia sofrido nenhum dano significativo. A partir de então, o próprio interior da llha e as áreas periféricas à capital foram sendo gradativamente ocupados.

(...) Além do desmatamento para a agricultura, através do corte e queima das árvores, percebe-se a intensa retirada de madeira para diversos usos." (CECCA, 1997, p. 47). 
A atividade humana é, direta ou indiretamente, responsável por grandes modificações na maior parte da cobertura vegetal do planeta, seja pela exploração dos recursos naturais ou pelas atividades corriqueiras do dia a dia. Ou seja, não é preciso se desmatar uma floresta, explorar minérios, alagar grandes áreas verdes para construção de hidroelétricas para causar danos no ambiente. O turismo é um exemplo de atividade que não parece prejudicar o meio ambiente, mas quando feito sem um planejamento adequado causa muitos impactos. Assim como a ocupação desordenada da llha; seu frágil ecossistema sofre com a conseqüente polvição das águas, destruição das áreas de preservação permanente, esgotamento do sistema viário, impermeabilização do solo.

As atividades econômicas na llha estão cada vez mais inseridas no setor terciário, sendo o turismo preponderante, delegando o setor primário ao esquecimento. A indústria do turismo propaga as belas paisagens que são o cartão de visita da llha sem investimento na preservação ambiental, apenas preocupada com uma preservação meramente estética, não resgatando as áreas naturais da llha como recursos para a boa qualidade de vida.

Desde o início da atividade turística, sua relação com o meio ambiente é um tanto quanto conturbada. No ponto de vista de alguns estudiosos, a atividade turística está ligada diretamente com o meio ambiente e é apontada como um dos principais depreciadores do ambiente explorado, conseqüência da exploração desordenada do ambiente natural. "Florianópolis, que perdeu em meio século a sua original personalidade, agora vem tentando se firmar basicamente na atividade turística. (...) Os empresários e os políticos relacionados ao setor, ainda não o (mar) levam em conta e atualmente vêm clamando por novos aterros, estradas, duplicações, viadutos e túneis, para alcançar a modernidade turística." (CECCA, 1997, p. 60). Entretanto poderia ser uma alternativa viável para proteger o meio ambiente.

Os impactos ambientais causados nesses últimos anos pela exploração desordenada do ambiente natural são preocupantes. São alterações diretas na paisagem, pois alterando o ritmo da fauna e flora ocorre à redução da biodiversidade ecológica, biológica, geológica e cultural da região. Apesar de não conhecer exatamente os impactos causados na fauna, sabe-se que há um aumento das espécies mais tolerantes ao homem e uma diminuição dos mais sensíveis. Os problemas para o solo são mais visíveis: compactação, redução da capacidade de retenção de água, redução da capacidade de sustentar vida vegetal e animal e consequentemente erosão. A vegetação sofre direta e indiretamente com a compactação do solo, a erosão deixa as raízes das plantas expostas, prejudicando sua sustentação e deixando-as vulneráveis a contaminação por pragas.

A condição de ilha, outrora positiva pela grande diversidade de ambientes, agora impõe limites por ser um ambiente frágil, que se não for bem preservado pode alcançar um quadro futuro irreversível de degradação ambiental e, portanto, de deterioração da qualidade de vida na ilha de Santa Catarina. A falta de harmonia entre a atividade turística e o meio ambiente sugere uma carência de planejamento para a atividade e conscientização dos turistas e da própria população local.

O parcelamento do solo na ilha é herança da antiga Desterro, onde predomina a divisão da terra em parcelamento de pequenas áreas antes destinadas a agricultura ou desmembramento, e alguns loteamentos esparsos pelo território. A partir dos anos 70 esses lotes foram crescendo sem a participação do poder municipal em sua estruturação e planejamento. Encontramos ruas estreitas e longas (chamadas servidões) que abastecem uma via principal, freqüentemente congestionada. Os loteamentos ocorrem em grandes áreas impróprias para a agricultura, como em encostas, banhados e dunas. Também a partir dos anos 70 essas grandes parcelas de terra foram ocupadas por grandes empreendimentos imobiliários, formando estruturas urbanas com sistema viário organizados em malhas regulares e pouco articuladas com o resto da cidade e ainda, e em muitos casos em áreas de preservação. 
Acredita-se que os impactos ambientais decorridos das atividades turísticas devem-se a uma ausência de um planejamento eficaz que poderiam ser minimizados sobretudo com algumas medidas paliativas com a colaboração de diversos setores da sociedade.

A atividade turística influencia diretamente nas áreas urbanas e naturais. A construção de equipamentos e instalações nos balneários da llha é prova dessa influencia na configuração e produção do espaço urbano. Sendo assim, os meios de hospedagem são indicadores eficientes do turismo na região. Com as informações recolhidas em hotéis, resorts, albergues, pousadas... é possível ter uma idéia da variação do número de turistas, seu poder aquisitivo, a época de maior temporada... As estatísticas de 2005 da Santa Catarina Turismos S. A. (SANTUR, 2005) estima 574.098 turistas, entre nacionais e estrangeiros, nesse ano, preenchendo $72,46 \%$ da rede hoteleira. Apenas 15,89\% dos turistas se hospedaram em hotéis, a grande maioria ficou em casa de amigos ou parentes (34,20\%), em casa ou apartamento de aluguel $(24,33 \%)$, em pousadas (12,03\%), entre outros. Mais da metade dos viajantes foi influenciado a visitar a cidade por amigos ou parentes; outros motivos foram a internet, folhetos de propaganda, televisão, revistas, jornais... Esses turistas deixaram na cidade o equivalente a 169.090.856,43 dólares e 94,21\% pretende retornar neste ano. Dentre os principais atrativos turísticos, o mais citado "atrativos naturais" (73,52\%), seguido por "visita a amigos/parentes" (16,77\%), "atrativos histórico-culturais" (5,39\%) e "eventos" (2,58\%).

\section{Paisagem}

A paisagem, com certeza, é um elemento de grande importância na atividade turística. É difícil achar uma definição, pois cada indivíduo interpreta a mesma paisagem de maneira diferente, de acordo com sua cultura, experiências, emoções... Macedo a define como "a expressão morfológica das diferentes formas de ocupação e, portanto, de transformação do ambiente em um determinado tempo" (1999, p. 11). Olmsted tem uma visão da paisagem como uma "contínua interação entre sociedade e território, em contraste com o modelo de parque-jardim europeu continental, que redesenhava a 'natureza' como um ideal de perfeição, a ser melhor observada de um ponto de vista exterior" (PELLEGRINO, 2000, p. 163).

A arquitetura da paisagem, também chamada de paisagismo, é o nome dado às diferentes escalas de ação sobre a paisagem, desde o plantio de um jardim até grandes projetos na cidade. "O plantio solitário de vegetação, posterior à definição de pisos, de paredes, de águas e de equipamentos, atividade comumente denominada de paisagismo, não pode ser considerado, em geral, como um procedimento de arquitetura paisagística, já que é utilizado, na maioria das vezes, como uma ação decorativa, sem nenhuma intenção de organização tridimensional e estrutural do espaço." (MACEDO, 1999, p. 14). O termo paisagismo é mais utilizado em ações decorativas, enquanto grandes projetos de praças, parques, calçadões e outras paisagens urbanas são denominados arquitetura da paisagem, pois esse tem o objetivo de organizar tridimensional e estruturalmente o espaço. Ao contrário do que se pode imaginar, o projeto de arquitetura não exige necessariamente a utilização de vegetação, precisa apenas de um espaço livre ao qual será aplicado o projeto, como, por exemplo, o calçadão de praia, em que a própria praia, os edifícios e o mar definem a estrutura espacial. "A paisagem é constituída não somente por espaços livres mas também pelo relevo, pelas águas, construções, estradas, formas de propriedade do solo, ações humanas decorrentes (como plantios e edificações), e, finalmente, pelo comportamento (individual e coletivo) dos seres humanos." (MACEDO, 1999 , p. 15). A construção de paisagens não é realizada apenas por especialistas. Elas sofrem constantes alterações, seja pela ação do homem, animais ou agentes do tempo. Por isso é impossível ter um ambiente totalmente projetado, mas apenas fragmentos dele. Todo esse planejamento do ambiente, além de diminuir os impactos causados pelo turismo, serviria como atrativo para outros turistas. 
Os moradores de áreas urbanas e demais espaços intensamente processados tendem a imaginar que gramados, lagos artificiais e árvores ornamentais sejam a imagem da natureza, quando na verdade ela ainda aparece dentro da malha urbana. "De acordo com a visão comum, a natureza começa onde a cidade acaba, como se houvesse um limite intransponível entre a paisagem cultural e a natural, como entre as manchas pintadas de vermelho e de verde nos mapas, ou seja, entre o ambiente construído e a paisagem intocada: a cidade como inimiga da natureza..." (PELLEGRINO, 2000, p. 162).

"O projeto de paisagismo situa-se sempre no limiar dos conflitos. Conflito entre a cidade e o campo, entre o solo e a água, entre o interior e o exterior dos edifícios, conflito entre o social e o natural. O que determina seu caráter sintético e formal. Considerando-se a forma como coesão momentânea de conflitos entre conteúdos." (PELLEGRINO, 2000, p. 163). Por isso, dependendo da estratégia adotada, o projeto de paisagismo pode tanto unir essas características contrastante e fazer com que se inter-relacionem, ou, o que ocorre na maioria dos casos, bloquear e destruir conexões entre elas.

"A partir do paradigma de percepção de que só conseguimos perceber o que conseguimos interpretar (PEIRCE, 1974), a legibilidade da paisagem torna-se possível no momento em que fragmentos da realidade são retirados para observação atenta, permitindo a qualificação do ambiente e sua interpretação."

\section{Legislação urbana}

Um grande aliado na luta para a proteção do ambiente é a legislação urbana, mais especificamente o Plano Diretor. O primeiro da cidade data de 1955 e o mais recente é do ano de 1998. O Plano Diretor é um conjunto de leis municipais que estabelecem diretrizes para a ocupação urbana do seu território, determinando o que pode e o que não pode ser feito em cada parte da cidade. Desta forma, busca direcionar a forma de crescimento tendo como princípios uma melhor qualidade de vida e a preservação dos recursos naturais. De acordo com o artigo 41 do Estatuto da Cidade (Lei Federal n. 10.257 de 10/07/2001), existe a obrigatoriedade do Plano Diretor para cidades: I) com mais de 20 mil habitantes; II) integrantes de regiões metropolitanas e aglomerações urbanas; III) onde o Poder Público Municipal pretenda utilizar os instrumentos previstos no $\S 4^{0}$ do art. 182 da Constituição Federal; IV) integrantes de áreas de especial interesse turístico; V) inseridas na área de influência de empreendimentos ou atividades com significativo impacto ambiental de âmbito regional ou nacional. É constituído por documentos de informação e análise (diagnósticos, relatórios, mapas); documentos de orientação (definição de políticas, diretrizes, estratégias); documentos operativos (planos de ação, projetos); documentos normativos (projetos de lei).

\section{Métodos}

A revisão de literatura priorizou o fenômeno do turismo e sua inserção espacial na paisagem urbana, natural e construída da llha. A coleta de dados foi através da observação (sistemática, individual, em equipe, na vida real e em laboratório), às vezes auxiliada por entrevista estruturada. $\bigcirc$ auxílio de recursos computacionais ampliou as possibilidades de compreensão de cada evento. Através do isolamento de atributos inerentes a um fenômeno específico e cruzamento entre estes é possível compreender as relações e o comportamento das variáveis que atuam sobre ele. A análise do uso e ocupação do solo passa pela compreensão dos elementos indutores de transformação do espaço urbano e são visualizadas através dos mapas temáticos oriundos do SIG. As interferências ambientais na paisagem da ilha de Santa Catarina são visualizadas através dos cruzamentos de suas concentrações e das áreas de conflitos ambientais. 


\section{Confecção da base}

Para a confecção da base, foi usado arquivo com as curvas de nível de toda a ilha de Santa Catarina. Essas curvas foram georreferenciadas e sobrepostas a uma foto da ilha - também georreferenciada - de satélite para que suas imperfeições no contorno e curvas abertas fossem corrigidas e não acarretassem problemas mais adiante.

A composição do mapa de zoneamento baseou-se de informações do site do Instituto de Planejamento Urbano de Florianópolis (IPUF), na seção "Pré-Consulta de Viabilidade", opção "zoneamento". Cada prancha foi copiada e recortada separadamente para que pudesse ser recomposto o mapa de zoneamento. Ajustaram-se as pranchas e um grande mosaico do zoneamento da llha foi formado.

Em seguida, esse mosaico foi exportado onde foram feitos, separados por layers (camadas) e cores, os contornos para cada área, como por exemplo: área residencial exclusiva (ARE), área residencial predominante (ARP), área de preservação permanente (APP), área de preservação com uso limitado (APL), área de exploração rural (AER), área mista central (AMC)... A partir desse, foi criado outro mapa com três divisões apenas: áreas consideradas passíveis de ocupação, APP e APL. Aplicando as informações contidas no Plano Diretor a respeito da taxa de ocupação de cada uma das áreas, foi possível verificar o número de habitantes previsto pela lei para a ilha, que é de aproximadamente 1.361.645 habitantes.

O último passo foi dividir a ilha em regiões homogêneas: Canasvieiras, Cachoeira do Bom Jesus, Ingleses do Rio Vermelho, São João do Rio Vermelho, Ratones, Santo Antônio de Lisboa, Sede (Centro), Lagoa da Conceição, Ribeirão da Ilha, Pântano do Sul, Campeche e Barra da Lagoa. A partir desse mapa será verificado o número de habitantes e de equipamentos de hospedagem em cada uma das regiões homogêneas.

\section{Conclusões}

Este estudo identifica estratégias e ações que visem à proteção dos ecossistemas urbanos em direção a um desenvolvimento integrado e duradouro. Mais especificamente, utilizando-se do indicador "meios de hospedagem", são verificadas as localidades sob maior demanda turística, e caracterizado o estágio de desenvolvimento turístico e o desgaste ambiental resultante na área. Através da elaboração de mapas temáticos, são valorizados com mais detalhes amostras significativas de ocupação, envolvendo usos turísticos, suas localizações e sua situação conflituosa, ou não, em relação ao meio ambiente. Esta verificação possibilita a ampliação das informações espaciais de uso e ocupação do solo e das possibilidades de desenvolvimento do turismo na escala da ilha de Santa Catarina.

\section{Bibliografia}

AMBRÓSIO, Edson Luiz. A explosão do turismo, 2002.

COSTA, Jean Henrique. Turismo - Uma síntese teórica, 2002.

FARIA, Ana Lúcia; SANTIAGO, Alina. A importância da atividade turística como elemento na configuração dos espaços da llha de Santa Catarina.

KNAFOU, Remy. Turismo e território: por uma abordagem científica o turismo. In: RODRIGUES, Adyr A. B. (Org.). Turismo e geografia: Reflexões teóricas e enfoques regionais. São Paulo: Hucitec, 1996. 
PELLEGRINO, Paulo R. M. A Ecologia da Paisagem. In: MACEDO, Silvio S. Paisagem e Ambiente: Ensaios. São Paulo: FAUUSP, v. 9, p. 47-81, 1996.

Pode-se Planejar a Paisagem? In: MACEDO, Silvio S. Paisagem e Ambiente: Ensaios. São Paulo: FAUUSP, v. 13, p. 159-179, 2000.

SILVA, Jorge; FRANZONI, Tereza. Florianópolis, cidade insular. In: CECCA. Uma cidade numa ilha. Florianópolis: Editora Insular, 1996.

\section{Consultas pela Internet:}

<http://www.agecom.ufsc.br/principal.php?id=1453>. Acesso em: 30/01/2005;

<http://revistaturismo.cidadeinternet.com.br/artigos/paisagem.html>. Acesso em: 01/02/2006;

<http://www.pmf.sc.gov.br/index.php?link=perfil\&sublink=fisico_geog >. Acesso em: 01/02/2006;

<http://www.agetur.go.gov.br/tipo_tur.htm>. Acesso em: 07/02/2006;

<http://www.portaldailha.com.br/turismo>. Acesso em: 09/02/2006;

<http://www.sol.sc.gov.br/santur/FrameDemanda2005.asp?Link=Floripa.htm>. Acesso em: 09/02/2006;

<http://www.vel.br/cca/agro/ecologia_da_paisagem/cursos/biota_paisagem.pdf>. Acesso em: 10/02/2006. 